\title{
LATIN AMERICA SCHOOL OF BUSINESS TAUGHT (LASBT): AN INITIAL REFLEXION
}

\author{
Escuela Latinoamericana de Negocios (ELN): Una reflexión inicial
}

\author{
Oscar Javier Montiel Méndez* \\ https://orcid.org/0000-0003-0434-1649
}

\begin{abstract}
RECIBIDO: Mayo 2021 / ACEPTADO: Julio 2021 / PUBLICADO: Septiembre 2021
\end{abstract}
Como citar: Montiel Méndez, Oscar Javier. (2021). Latin America School of Business Taught (LASBT):

An initial reflexion. Telos: revista de Estudios Interdisciplinarios en Ciencias Sociales, 23 (3), Venezuela. (Pp. 659-666).

DOI: www.doi.org/10.36390/telos 233.10

\begin{abstract}
"We only reviewed papers written in English. One reason for doing this is that theory in entrepreneurship originated in North America and Europe, two regions that have positioned themselves at the research frontier and have relatively mature research findings. Another reason is that English is popular in academia and papers published in English can easily circulate in different countries" (Lu, Lu, Lv, Huang, Li, Jian, and Reve, 2020).
\end{abstract}

Enough. Is it time for the constitution of a Latin American School of Business Taught? To found it. To have our position. What contributions has Latin America made theoretically and empirically in Business, in the academic literature of Creativity, Management, Innovation, Entrepreneurship, Family Business, Business History, and other related disciplines? Where are we positioned in the history of global research and academic debates?

Remember the Frankfurt School. It was built upon comprised intellectuals, academics, and political dissidents dissatisfied with the era's socio-economic systems (capitalism, fascism, communism). The Frankfurt theorists believed the social theory of that time was inadequate for explaining the socio-political movements occurring in 20th-century liberal capitalist societies, so the School's critical theory research proposed alternative paths for the social development of a society, a territory, and the individual (Held, 1980). Any remembrance for the Latin America (LATAM) academic's discomfort with the constant importation of theories, and different calls for an own, regional, and more inclusive theories in different research streams?

Horkheimer (1976) proposed critical theory as a social theory oriented toward critiquing and changing society, in contrast to traditional theory oriented towards understanding or

*Universidad Autónoma de Ciudad Juárez (UACJ), México. Correo electrónico: oscar.montiel@uacj.mx 
explaining it. This was part of the Frankfurt School manifesto, and it is suggested to be a crucial element that should also be part of any LATAM perspective.

Thus, decolonial methodologies are becoming increasingly familiar in the Management and Organization Studies field (MOS). When we are called to 'decolonize', it should be noted that our work itself can reproduce the structural oppressions that we set out to disrupt at the beginning (Lorde, 1984).

Smith (2012) suggests that research is a space where coloniality is rearticulated, resulting in silencing the voices of the marginalized. As researchers, we should then recover and begin to self-determine the roads (theories and methods) that best suit our Latin American reality'. Raise our voices. Mignolo $(2009$, p. 3) notes: "The de-colonial option is the singular connector of a diversity of de-colonials. The de-colonial path has one thing in common: the colonial wound, the fact that regions and people worldwide have been classified as underdeveloped economically and mentally".

So then, the process implies to be dissent, critically approaching "the "truth". Can we redesign Eurocentric or Western methodologies (and theories) to be more inclusive (Lincoln, Gonzalez and Gonzalez, 2008) or create and propose new ones? Epistemic emancipation (De Lissovoy, 2015). It is time to be recognized, visible for other academic fields, who until today, seem to care not much about us. Creating a new, distinctive school implies acknowledging what has been done, evaluating ethnocentrism, decolonizing and proposing regional theories ${ }^{2}$, our reality. We live in a fertile and rich territory to explore. To contribute more on a global scale. What are subjects still pending to explore, under a new, anti-paradigmatically, in and for our region? Where do we need to go? This is a historic time for our research community to stand out and raise its concerns. Let us reflect, recognizing strengths, weaknesses, being inclusive with other regions as well.

\section{Diverse positions and concerns}

So many opportunity areas. For example, Creativity studies are broad and heteroclites since the beginning of the last century have been a concept approached as the result of applied imagination (Ribot, 1901), from an increasingly utilitarian position (De Bono, 1985) to more humanistic approaches such as Maslow (1994), or psychosocial (Csikszentmihályi, 1990). However, in Latin America creativity scholars appear to remain scarce except for few contributions, like those of Mauro Rodríguez Estrada (1936-2007).

Innovation has focused on opportunities to generate sustainable competitive advantages over a period until other companies outweigh these (Mothe and Nguyen, 2010). However, innovation goes beyond the economic and technological since it has moved to other areas such as social or political and has positioned itself as a critical driver for local development where dissimilar contexts are a constant. What are the empirical and theoretical opportunities that emerge in innovation in Latin America based on territorial capital? How does the context in Latin America influence the development of innovation policies regionally and globally? What innovations trigger social and productive transformations, fighting social inequality in different

\footnotetext{
${ }^{1}$ See Leopoldo Zea and his position for a Latin American philosophy (Cacciatore, 2004).

${ }^{2}$ Spaces like the Latin American and European Meeting on Organization Studies (LAEMOS) also have been making this call. See also Soto \& Gomez (2018) on researching models for histories of science, technology, and medicine (STM) in LATAM.
} 
industries, sectors, and types of organizations in Latin America? An area of opportunity for a regional and, therefore, global theoretical and empirical contribution.

In addition, Welter and Gartner (2016) point out the importance of contextualizing the different views on Entrepreneurship, contributing to a better understanding of this construct, reflecting critically, and how it shaping theory. Also, Shalley, Hitt, and Zhou (2015) mention the growing interest in integrating entrepreneurship into other research areas, specifically creativity and innovation, which have existed independently. This suggests that entrepreneurship and management, in general, are increasingly seen under a kaleidoscope, with multiple edges. That is why Welter and Gartner (2016) questions how we can contextualize the theories, and how it re-signifies the contexts for the public policies that support entrepreneurship. However, it is also pertinent to question the weight of historical environments.

Is it time for a regional theory of entrepreneurship, creativity, and innovation, that considers the vast and profound historical legacy, from our Mesoamerican cultures, the Spanish conquest, the independence process throughout the continent, and the late $19^{\text {th }}$ and $20^{\text {th }}$ centuries development, and its socioeconomic, political and cultural impact on our communities, barriers that are there, a continuum that does not let us advance?

In economics (Jasso, Del Valle, and Nuñez, 2017), there were efforts in the $20^{\text {th }}$ century that try to find a regional way to grow and develop. Prebisch (1949) is the originator of Latin American Economic development thought, which is based on the theoretical approach that we could refer to as structuralism cepalino (from Economic Commission for Latin America (ECLA, CEPAL in Spanish).

In innovation, Del Valle, Jasso, and Nuñez (2016) advocates that in Latin America, there have been important theoretical advances to explain and develop science, technology, and innovation. In their book, they show the ideas of eleven Latin American thinkers who have made important theoretical and public policy contributions concerning science, technology, and innovation. It is suggested they defined a theoretical-critical and propositional approach that on many occasions led to creative public policy proposals and promoted a certain technological development in the region. But many models were imported and did not have the impact and development they were supposed to have. So, did they create a Latin American school? If it is, where is then LATAM's technological sovereignty, economic development, the obvious and expected outcome? Why the region still struggles with poverty? What school replaced the cepalina school, a 1940's economic vision for our region that positively impacted our region?

Were those individuals' efforts, and never were amalgamate as a solid regional thought? Is the region still on an incessant mode of finding a strategy congruent with its historical, social, cultural, and economic reality, to build its development ${ }^{3}$ ? Does the western hemisphere remember that Sábato's triangle (1971) is the precursor of the Triple Helix model (Etzkowitz and Leydesdorff, 1995)?

Aguinis, Villamor, Lazzarini, Vassolo, Amorós, and Allen (2020) further point out this dynamic in the management field, where research conducted in this area in the United States and other developed countries makes assumptions. Usually implicitly, on diverse management scopes, and argue that the peculiar characteristics of Latin America allow to build and test theories that do not necessarily rely on these assumptions.

${ }^{3}$ Villagrán (1991) also reflects on this, but towards intellectual creativity. 
A growing interest in our region is evident. The number of Special Issues has been rising recently (Cancino, Merigó, Urbano, and Amorós, 2020). But no reference or exploration about LASBT has been put forward. Just recently, Ruiz-Martínez, Kuschel, and Pastor (2021) make a call for a Latin American research perspective on women entrepreneurs. Fostering this suggestion will contribute to regional development, not only impacting economic indicators but as well social ones, like gender issues. Also, Guerrero (2021) highlights the diversity in incubation mechanisms used in LATAM, public, private, partnerships with mixed organizational structures to support the creation and development of entrepreneurial initiatives but points out how the literature on incubation has predominantly paid attention to the North American and Western European experience with little or no mention on other contexts. A colonial view that should not be.

Some recent efforts are the 2019 call for the Special issue on 'Management Accounting in Latin America', from the Spanish Journal of Finance and Accounting ${ }^{4}$, where the guest editors acknowledge the research in this area has been published almost exclusively in Portuguese and Spanish languages, leading to limited visibility and exposure to the international academic community, where the design, adoption, and use of management accounting practices in the region are scarce and fragmented. Also, The Latin American Academy of Management (LATAM) Specialized Conference in 2020, "Beyond Research: Advancing Management Research in Latin America" 5 , foster the development of research from the region's scholars and institutions. Or the 2020 Call for Papers on "Family Business in Latin America" from the Journal of Family Business Strategy ${ }^{6}$, where the guest editors intend to provide a forum for cutting-edge research on family business and to pave the road for more future studies to occur, and in the same year the Special issue from European Business Review, entitled The Entrepreneurship Challenges in Latin America. And coming in 2022, the "Handbook of Entrepreneurship in Latin America: Unleashing a millennial potential". The first of its kind in LATAM history, Oscar Montiel and Araceli Almaraz, Editors.

In every case, ethnocentrism has been played a decisive role in which research has been done in our region, in most cases importing theories and research methods. Also, the language barrier has always been an issue. Maybe our researchers have been conformist, not wanting to take risks, or the educational/scientific system in our region does not reward enough original global regional contributions the researcher does, e.g., Paulo Freire global influence on critical pedagogy (Freire,1985).

Building LASBT on areas related to Business, especially under Covid-19 times, is historically more relevant than ever before. The conditions are extremely difficult, and new ways of approaching our reality are superlative. Each area should rescue research conducted between the $19^{\text {th }}$ and $20^{\text {th }}$ centuries until the present days and state very clearly what has been its methodological, and epistemic position and key issues that are its concerns regarding our region.

\footnotetext{
${ }^{4}$ https://www.tandfonline.com/doi/full/10.1080/02102412.2019.1632522

5 https://aom.org/events/specialized-conferences/past-specialized-conferences/mexico-advancing-management-research-in-latinamerica

$\underline{{ }^{6} \text { https://www.sciencedirect.com/science/article/pii/S1877858520300978 }}$
} 


\section{The turning point: The Special Issue}

A team of researchers was invited to write papers on Creativity, Management, Innovation, Entrepreneurship, Family Businesses, Business History, and other related disciplines, and reflect also on the following general, intended provocative questions:

1. How did $X$ ( $X=$ area of research) emerge or born in Latin America?

2. Which has been the main contribution theoretically and empirically that Latin America has given to $\mathrm{X}$ regionally and globally?

2. What role does ethnocentrism has been playing in Latin America regarding $X$ ?

3. What have been the academic and personal research experiences of the authors regarding this issue?

4. If it does not exist, What does it need to create a Latin American school of $X$ ?

5. What are the cultural, institutional, and social obstacles the Latin American researchers in $X$ have that block their willingness to explore the global academic arena? And the general context? Challenges?

6. What are the future opportunities in Latin America for $X$ ?

A future manifesto, initiative, should incorporate these questions as a starting point.

This special issue also had the aim to bring on the latest debates on managementrelated disciplines in Latin America. Each theme tried to recover the different perspectives researchers from this region had and have on theoretical and empirical advances historically. And at the same time, the multiplicity of processes in the national and subnational spaces, to understand the future challenges for Latin America, and especially a view of its competitive future, a better understanding of this region in the global debate.

It is a first step in trying to converge different research streams into a similar call to embrace the possibility to start a new era in Latin American scholarly history. The call made by Flores, Bojorquez y Cuadrado on women entrepreneurship and the difficulties context present for them, dissimilar in many ways from those in Western countries not only in the tools they implement but also on the need of a general theory that highlight the specific needs of our countries, the reflexion made by Mandujano on the potential to establish a new research stream on Latin American East Asia studies, given the large Asian communities living in the region, and the increasingly foreign direct investments they have been doing in recent years, permeating its influence across multiples layers or our societies; the conditions and complexities involved in strengthening the discussion putting forward by Alvarez and Palacios about the functionality of a Latin-American school of innovation, where its cultural, institutional and social obstacles are challenging the way to do research and teaching; the until now disperse contributions from Latin America to business anthropology made by Santos and de Gortari; the difficulties on doing social innovation in Latin American context from Vargas and Escudero; are some of the areas where Latin American is present and where contributions has been made.

\section{Final words}

Aguinis, Villamor, Lazzarini, Vassolo, Amorós, and Allen (2020) stated four different challenges Latin American researchers are confronted with (p. 627): "(a) lack of researchoriented careers and insufficient research resources, (b) limited networking and collaboration 
opportunities, (c) local regulatory systems and rankings not always based on research quality, and (d) prejudice against data collected in non-U.S. contexts".

The first three might be more of a wrong personnel selection by the institutions, where they do not select from a vocationally oriented process and do not consider academic entrepreneurial competencies as a requisite. And about the latter (d), yes, it is still out there. But no matter how hard the conditions are, if there is the passion for being or becoming a researcher looking to transcend and make a meaningful career with an impact on the global arena, one must be creative and try to find gaps and strategies to face the different tough hurdles the Latin American context do have.

The researchers in this special issue have been put efforts to lead the counter-narrative Western narrative and try to find an own regional voice, escape from the box and start a breaking point for our prevailing research culture that systemically stigmatizes, ignore and waste LATAM research. Scientific knowledge does not need this external recognition; it is valuable and recognizable in itself. But in the context, there are historical, ideology issues that we can ignore, which directly impact our daily lives, as individuals, and society. Finally, many thanks to Dr. Wileidys Artigas, editor in chief, for her trust and willingness to take the huge risk to involve in this heuristic exercise, and to Dr. Ulises Campbell, professor at UACJ, for his valuable points of view regarding this paper. Of course, more must be done in the following years, but this is a modest effort to raise the voice and attention of the Latin American researcher, and bring more consideration to what this region is and what it is generating, socially, economically, academically. It is a global player, and it is time to claim the place it deserves.

The time has come.

\section{Bibliographic references}

Aguinis, Herman; Villamor, Isabel; Lazzarini, Sergio; Vassolo, Roberto; Amorós, José; and Allen, David (2020). Conducting Management Research in Latin America: Why and What's In It for You? Journal of Management, 46(5), United States, (Pp. 615636). https://doi.org/10.1177/0149206320901581

Cacciatore, Guiseppe (2004). Una filosofía para América Latina: Leopoldo Zea. Telos. Revista de Estudios Interdisciplinarios en Ciencias Sociales, 6(1), Venezuela, (Pp. 9-24). http://ojs.urbe.edu/index.php/telos/article/view/1160

Cancino, Christian, Merigó, José, Urbano David and Amorós José (2020). Evolution of the entrepreneurship and innovation research in Ibero-America between 1986 and 2015, Journal of Small Business Management, (in press) United Kingdom, https://www.tandfonline.com/doi/full/10.1080/00472778.2020.1776578

Csikszentmihályi, Mihaly (1990). Flow: the psychology of optimal experience. Harper \& Row, United States.

De Bono, Edward (1985). Six Thinking Hats: An Essential Approach to Business Management. Little, Brown, \& Company, United States.

De Lissovoy, Noah (2015). Epistemology of Emancipation. In De Lissovoy Noah, Education and Emancipation in the Neoliberal Era. (Pp. 131-146). Palgrave Macmillan, United States.

Del Valle, María del Carmen; Jasso, Javier and Núñez, Ismael. (2016). Ciencia, tecnología, innovación y desarrollo. El pensamiento latinoamericano, FCE, UNAM, España. 
Etzkowitz, Henry and Leydesdorff, Loet (1995). The Triple Helix of university-industrygovernment relations: a laboratory for knowledge-based economic development, EASST Review, 14(1), Holland, (Pp. 11-19). https://papers.ssrn.com/sol3/papers.cfm?abstract_id=2480085

Freire, Paulo (1985). Pedagogía del oprimido. Siglo XXI Editores, México.

Guerrero, Maribel (2021). The role of incubators and accelerators in the Latin American entrepreneurship and innovation ecosystems. In Sarfraz A. Mian, Magnus Klofsten \& Wadid Lamine (Eds.), Handbook of Research on Business and Technology Incubation and Acceleration, A Global Perspective, (Pp. 335-350), Edward Elgar, Cheltenham, UK. https://www.e-elgar.com/shop/usd/handbook-of-research-onbusiness-and-technology-incubation-and-acceleration-9781788974776.html

Held, David (1980). Introduction to Critical Theory: Horkheimer to Habermas. University of California Press, United States.

Horkheimer, Max (1976). Traditional and Critical Theory, in Paul Connerton (ed.). Critical Sociology: Selected Readings, Penguin, United Kingdom.

Jasso, Javier; Del Valle, María del Carmen and Núñez, Ismael (2017). Innovation and development: a revision of the Latin American thought, Academia Revista Latinoamericana de Administración, 30 (4), United Kingdom, (Pp. 444-458). https://doi.org/10.1108/ARLA-09-2016-0249

Lincoln, Yvonna and González y González, Elsa (2008). The search for emerging decolonizing methodologies in qualitative research: Further strategies for liberatory and democratic inquiry. Qualitative Inquiry, 14(5), United States, (Pp. 784-805). https://doi.org/10.1177\%2F1077800408318304

Lorde, Audre (1984). The master's tools will never dismantle the master's house. Sister outsider: Essays and speeches, Crossing Press, United States.

Lu, Ren; Lu, Qu; Lv, Daguo; Huang, Yuxiang; Li, Shuping; Jian, Ze and Reve, Torger. (2020). The evolution process of entrepreneurship studies in the 21 st century: research insights from top business and economics journals. Journal of Economic Surveys, 34(4), United States (Pp.922-951). https://doi.org/10.1111/joes.12365

Maslow, Abraham (1994). La personalidad creadora, Kairos, España.

Mignolo, Walter (2009). Epistemic disobedience, independent thought, and decolonial freedom.

Theory, culture \& society, 26(7-8), United States, (Pp. 159-181). DOI https://doi.org/10.1177/0263276409349275

Mothe, Caroline and Nguyen, Thuc (2010). The link between non-technological innovations and technological innovation, European Journal of Innovation Management, 3(3), United Kingdom, (Pp. 313-332). https://doi.org/10.1108/14601061011060148

Prebisch, Raúl. (1949). El desarrollo económico de la América Latina y algunos de sus principales problemas, E/CN.12/89, CEPAL, Chile.

Ribot, Théodule (1901). Ensayo sobre la imaginación creadora. Librería de Victoriano Suárez, Librería de Fernando Fe, España.

Ruiz-Martínez, Rocío; Kuschel, Katherina and Pastor, Inmaculada (2021). A contextual approach to women's entrepreneurship in Latin America: impacting research and public policy. International Journal of Globalisation and Small Business, 12(1), Switzerland, (Pp. 83-103). http://www.inderscience.com/offer.php?id=113835 
Sábato, Jorge. (1971). Ciencia, Tecnología, Desarrollo y Dependencia, San Martín de Tucumán, Serie: Mensaje. Argentina.

Shalley, Christina; Hitt, Michael and Zhou, Jing. (Eds.). (2015). The Oxford handbook of creativity, innovation, and entrepreneurship. Oxford University Press, Oxford, UK. https://doi.org/10.1093/oxfordhb/9780199927678.001.0001

Smith, Linda (2012). Decolonizing methodologies: Research and indigenous peoples. Zed Books, United Kingdom.

Soto, Gabriela and Gómez, Pablo. (2018) Introduction, History and Technology, 34(1), United Kingdom, (Pp. 5-10), https://doi.org/10.1080/07341512.2018.1516848

Villagrán, Carlos (1991). Creatividad e investigación sobre la comunicación. Revista Mexicana de Ciencias Políticas y Sociales, 36(144), México (Pp. 27-38). DOI: https://doi.org/10.22201/fcpys.2448492xe.1991.144.51889

Welter, Friederike and Gartner, William (2016). A Research Agenda for Entrepreneurship and Context. Edward Elgar, Cheltenham, United Kingdom. 